\title{
Criticism and Reconstruction of the Origin of Judicial Authority in China
}

\author{
Yanpeng $\operatorname{Liu}^{1}$ \\ ${ }^{1}$ Institute of Law Chinses Academy of Social Sciences \\ Received: July 1, 2015 Accepted: July 14, 2015 Online Published: July 16, 2015 \\ doi:10.5430/wjss.v2n2p27 URL: http://dx.doi.org/10.5430/wjss.v2n2p27
}

\begin{abstract}
The precondition of establishing judicial authority is to study its origin. Currently, some misunderstandings exist in the analysis of origin of judicial authority in China's academic circles. The studies are proved to be either the direct copy of western authoritative theory, or the enumeration of practical factors that influence judicial authority. Chinese Scholars don't analyze the origin of judicial authority. After the critical analysis of various theories of domestic scholars, this paper puts forward three major authoritative origins in line with China's actual situations: power, public opinion and procedure.
\end{abstract}

Keywords: power, public opinion, procedure, origin of authority

The Third Plenary Session of the 18th CPC Central Committee indicated that efforts were to be made to deepen the reform of the justice system, to protect the people's rights and let the masses feel equality and justice in every court verdict. Judicial fairness, judicial efficiency and judicial authority are proposed by the Party and our country as the orientations and goals for further judicial reform of China. This paper discusses the origin of judicial authority and reveals what kind of factors can serve as the origin of judicial authority. As the problem of judicial authority dates from ancient times, the domestic and overseas judicature and laws both at present and in old days seek for the support of authority. In China, the Emperor's authority was declared as God-given, and Emperors' births were related to myths. The Emperors, whose words were laws that can decide one's life and death, called themselves the Son of Heaven. The laws enacted by the Emperor were labeled "the Law of Emperor". In west countries, the church heard a case in the name of God, so that western trials nowadays are still with religious characteristics. With the rise of the Enlightenment, God was dead, and people made laws for themselves. It was no longer possible for judicial decisions to rely on God to justify their legitimacy. At this point, enough authority needs to be found to support judicature.

At present, Chinese judicial authority has declined and affected the normal operation of social order. Therefore, disputes that could have been solved by judicature can only be managed through letter visits and mass incidents. Domestic scholars' researches on Chinese judicial authority focus on two aspects: 1. the origin of judicial authority; 2. the cause of decline of judicial authority and reconstruction approach. Most of scholars concentrate on the second aspect, listing various factors that damage judicial authority, such as low-quality of judicial officials, non-independence of judicature, low-efficiency of judicature and so on. But their researches lack the discussion of the origin of judicial authority. The author holds that the research of judicial authority needs to make clear the origin of judicial authority in theory, so that the problem of reconstruction of judicial authority can be solved at the sources. However, domestic scholars don't get to the core of the problem in analyzing the origin of judicial authority, so that various problems exist in their conclusions.

This paper is divided into three parts. Through criticism of domestic viewpoints of the origin of judicial authority, part one denies three viewpoints: 1. Judicial authority comes from legal authority; 2. Judicial authority comes from judicial fairness; 3. Judicial authority comes from the finality of judicial decisions. Part two puts forward and demonstrate that judicial authority comes from judicial power, public recognition and due procedure. Part three provides the conclusion related to the origin of judicial authority.

\section{Analysis and Criticism of the Origin of Judicial Authority}

\subsection{Judicial Authority Comes From Legal Authority}

Scholars who support this viewpoint hold that judicial authority comes from the confirmation and guarantee of 
judicial power by the Constitution and Law. Legal authority is the product of social development. In feudal society, the power of Emperor had supremacy, while law didn't. Law was not strictly observed and abided by people. Therefore, judicature, as the operation of law, never had authority. The author insists that it is proved to be a big problem to tie judicial authority to the authority of the Constitution and law, which is the main factor that contributes to the decline of judicial authority in China.

First of all, the Constitution endows the judicial organ with power, not authority. The Article126 and Article131 of China's Constitution state that judicial organ exercises judicial power independently, in accordance with the provisions of the law, and are not subject to interference by any administrative organ, public organization or individual. In practice, judicial power is not guaranteed, but interfered by administrative power and public opinion, so that judicial power loses its due authority. The power will lose its authority, when it cannot be implemented.

Secondly, legal authority cannot be transformed into judicial authority directly. The author maintains that people's recognition of law and obedience of legal authority have no necessary relation to recognition of judicial decisions and respect to judges. Although law has supremacy, judicial organ doesn't necessarily have authority. Because from emergence to apply of law, three stages are experienced: legislation, judicial practice and law enforcement. These three stages are linked with one another. The supremacy of law doesn't mean that judicature has authority. Even though law has supremacy, it is still possible that legislature and law enforcement have much more power, and judicature has little. In this case, does judicature have authority? It is suspectable. Therefore, the so called one origin of judicial authority-legal authority is inaccurate.

Finally, there is no necessary connection between judicial authority and social independence. In feudal society, the basis of legitimacy stems from the power of Emperor. With high concentration of power, judicial organ is also administrative organ, and feudal officials have extremely high prestige among people. From both the execution of judicial decisions and the obedience and trust of people, judicial organ in feudal society has authority. However in current society, legitimation crisis arises, so that judicial authority needs public recognition and constitutional justification. Therefore, the viewpoint that judicial authority developed in early modern times is inaccurate.

\subsection{Judicial Authority Comes From Judicial Fairness}

Scholars who support this viewpoint hold that judicial authority covers procedural justice and substantive justice. The establishment of judicial authority relies on not only open and transparent judicial actions, but also impartial and convincing judicial decisions. The author supports the viewpoint that judicial authority comes from procedural justice, but it is still questionable that there is necessary and inherent connection between judicial authority and substantive justice.

First of all, that judicature has no authority owing to judicial unfairness is not in line with judicial practice. In judicial practice, the phenomenon of misjudged cases is not serious. Take an example of the year 2011, the rate of accepting judgment after first instance reached $90.61 \%$, and after second instance reached $98.99 \%$. (Note 1) According to the research of Judge Liu Jiachen, misjudged cases only account for an extremely small percentage. Cases of letter visits are not caused by misjudgment. The rate of amending judgment is just about two chances in ten thousand. It is thus clear that the decline of judicial authority has no necessary relation to judicial unfairness.

Secondly, the viewpoint that judicial authority comes from substantive justice weakens judicial authority. Since judges need to ascertain and judge facts, choose relevant law and give judgment in judicial decisions, it is difficult for unprofessional people to objectively evaluate whether the judgment is impartial or not. The frequently-used judgment method of substantive justice for people is analogy - to observe whether judges can make consistent judicial decisions in similar cases, severe sentence for grave crimes and light sentence for minor crimes. Through this method, people always question the accuracy of judicial decisions, such as Li Changkui Case, which is the result of comparing with Yao Jiaxin Case. As for China's complicated national conditions, it is difficult for judges to make consistent judicial decisions in similar cases. In this case, to emphasize that substantive justice is the origin of judicial authority, judicial fairness will often be questioned, which does harm to the establishment of judicial authority.

At last, that judicial authority comes from substantive justice dislocates the cause and result. In a country where judicature has strong authority, they don't worry about unfairness of judicial decisions. On the contrary, people will endure judicial unfairness because of the authority of judicature. According to this logic, judicial authority is not the result of substantive justice, but at sometimes judicial authority provides guarantee for substantive justice, like O. J. Simpson murder case in America. American people could accept the judicial decision of Simpson's acquit of a charge not because they thought that Simpson is innocent, but they believed in judicial decisions. In America, a 
country owning strong judicial authority, the maintenance of judicial authority doesn't rely on substantive justice, but on their belief in procedural justice and judicature. In China, as judicature lost its due authority, the courts could not withstand the interference from government and other social institutions in some judgments, so that judicial fairness cannot be guaranteed.

\subsection{Judicial Authority Comes From Finality of Judicial Decisions—the Last Choice of Disputes Resolution}

Scholars who support this viewpoint hold that the finality of judicial decisions is the main origin of judicial authority. If the legally effective judgment given by judicial organ isn't a final one and can be overturned easily, the rights and obligations of different parties ascertained by judicial organ cannot be ensured finally. Therefore, it is hard to form judicial authority. The finality of judicature is one of the manifestations of judicial authority. Judicial decisions with authority can solve disputes and reconfirm the rights and obligations of different parties. However, the finality of judicature is not the origin of judicial authority.

First of all, we should distinguish the elements that damage judicial authority from the elements of the origin of judicial authority. There are a lot of elements influencing judicial authority, but not belonging to the origin of judicial authority, such as low-quality judicial officials, who cannot correctly apply law, is the factor that damage judicial authority, but not the origin of it. This is because high-quality of judicial officials should be one characteristic of judicature. The inner element cannot serve as the origin — an outer element. Similarly, the finality of judicature should be one characteristic of judicature and an element that damage judicial authority, but not the origin of judicial authority.

Secondly, we should distinguish the outward manifestations from inward origin of judicial authority. The former, in some ways, indicates that judicature has authority, while the latter directly provides authority for judicature. There are a lot of manifestations of judicial authority, such as the U.S. courts could review the constitutionality of legislation in specific cases. The review of constitutionality of courts is not the origin of judicial authority, but a manifestation of judicial authority. Here, the court's authority comes from its power to review constitutionality, which provides authority for courts. In the same case, the finality of judicature is a manifestation of judicial power. The real origin of judicial authority is judicial power, not the finality of judicature.

At last, we should distinguish causes of having authority from taking authority as causes. The former can be taken as the foundation of some organizations or individuals having authority, and also the origin of authority. The latter is taking authority as causes to do something. The difference between them lies in that cause is the sufficient condition for the former, while cause is the necessary condition for the latter. Taking ancestral lineage proposed by Leslie Lipson as an example, (Note 2) "If someone is the legitimate successor of the emperor, he will have the authority of emperor after ascending the throne." Here, the legitimate successor is the sufficient condition of having authority and also the cause of authority. "The emperor can decide the next successor." To decide the next successor takes having authority as its precondition and cause. In terms of the relation between the finality of judicature and judicial authority, judicial authority contributes to the finality of judiciary, but finality of judiciary cannot necessarily contributes to judicial authority. Because finality of judicature doesn't mean that judicial decisions can necessarily be enforced or obeyed. Finality of judicatre takes judicial authority as its cause, but cannot become the cause of judicial authority. Therefore, finality of judiciary cannot serve as the origin of judicial authority.

\section{Reconstruction of the Origin of Judicial Authority}

The previous part criticizes three viewpoints that judicial authority comes from legal authority, substantive justice and finality of judicature. When studying the essence of the origin of judicature, we need to combine domestic and overseas theories and Chinese practical conditions. (Note 3) The author holds that judicial authority comes from three aspects: judicial power, public recognition and due procedure.

\subsection{Origin One-Judicial Power}

The prerequisite of judicial authority is that judiciary has power. The power of judicial organ comes from authorization, no matter in dictatorial government or democratic government. Authorization of power provides judicial organ with the legitimate qualification to change the rights and obligations of different parties. This power that can influence people's behaviors possesses authority in its operation. (Note 4) Judicial power is considered as an important origin of judicial authority. The reasons are as follows:

First of all, from a logical point of view, judicial power is the prerequisite of judicial authority. The formation of judicial authority requires "power" firstly, and then "force". We can make out the relation between authority and 
power(right) from the definition of authority given by scholars. Joseph Raz holds that authority is a kind of ability to influence the behaviors of others. Talcott Parsons insists that authority is a kind of "systematically integrated right". James S. Coleman holds that authority is "the right to control behaviors of others". These three definitions reach the conclusion that the essence of authority is authorized power, although they discussed it from different perspectives. Of cause, not all powers can transform into authority. Only in two conditions can power transform into authority: legitimate power and power needed to be implemented. (Note 5)

Secondly, from the perspective of fact, the lack of judicial authority contributes to the non-execution of judicial power. The execution of judicial decisions is an important manifestation of judicial authority. However, difficulty of judgment execution, especially judgment of administrative proceedings, has become a serious problem in damaging judicial authority in China. According to the investigation and survey from Sichuan Province, $20 \%$ and more people think that common people cannot win the case; the difficulty of judgment execution gives rise to "local protectionism and administrative pressure"; more than $30 \%$ people and officials believe that government is the leader of court. Although this survey reflects the situation of a province, it is the epitome of national judicial situation. Therefore, whether the judicial power can be executed will affect judicial authority.

At last, from the perspective of effect, judicial power is the protection of judicial authority in all stages. Judicial power can guarantee the status and prestige of judicial officials and protect them not to be criticized, insulted, abused, and sieged. In the trial, judicial power can maintain judicial order, so that judges can deter and punish people's contempt of court and impact on judicial organ through admonishment, ordering to leave courtroom, penalty, and detention. Judicial power can guarantee res judicata and avoid the interference of non-legal factors that weaken judicial authority, so that the cases won't be protracted and lawsuits can be settled after final judgment. The accurate application of judicial power deters and punishes those who have disregard of judicial officials, judicial order and judgments, so as to maintain judicial authority furthest.

\subsection{Origin Two-Public Recognition}

Although academic circle emphasizes judicial independence that judicature should not be interfered by administrative organ, public organization or individual, in fact, public opinion influences judicature time and again. Most of scholars insist that the influence of public opinions to judicature should be effectively avoided, (Note 6) but very few of them think deeply of positive meanings of public opinions from the perspective of authority. For democratic government, its legitimacy and power comes ultimately from public recognition and authorization, not moral argument. As far as judicial authority is concerned, judicial power is merely the prerequisite of authority, but public recognition and obedience are the real foothold of judicial authority. Public recognition can become the origin of judicial authority for several reasons:

First of all, judicial authority is based on public choice. There are many dispute resolution methods, including reconciliation, mediation and lawsuit. Judicature is just one method of them. We give up our rights in choosing those methods, which endows the selected one right or qualification to determine our destiny. For example, if someone chooses to take an interview, the interviewer was endowed the qualification to determine the destiny of interviewee, so that the interviewer has the absolute authority. Take another example, if someone chooses to believe in a religion, the spiritual leader of this religion will have authority on this person. It is the same case for judicial authority, when people choose judicial organ, the judicial organ possesses the qualification to determine their destiny and has authority. Therefore, the foundation of judicial authority is public choice.

Secondly, judicial authority can be consolidated from public recognition. When judgments settle the disputes between two parties and achieve public recognition, judicature indicates a kind of demonstration effect. This demonstration effect can prompt more people willing to reach judicature to solve their disputes, so that judicial power can be intensified and permeated into various aspects of society. Therefore, public recognition can strengthen judicial authority. On the contrary, in some situations, judicature refuses public appeals, and some disputes cannot be solved by lawsuits, such as no case-filing of compulsory demolition and removal. This kind of self-destruction of judicial organ severely damage judicial authority.

At last, judicial authority exist in name only because of the query of public opinion. The previous part has already explained that judicial authority doesn't come from substantive justice. It is needed to supplement that although substantive justice is not the origin of judicial authority, it is the reason of public recognition on judicial organ. Even though some judgments are not in line with substantive justice, if people recognize it, judicial authority can still be maintained. (Note 7) The so called substantive justice not only requires that judgments should accord with facts and laws, but also requires that judgments should conform to the vague justice in public opinion. From the content and essence of authority, substantive justice is the content of judicial authority, while the public recognition is the essence. 
Therefore, if people query about it, the judicial authority cannot be established, even though the judgment is impartial.

\subsection{Origin Three-Due Procedure}

Strictly speaking, China has the tradition of "emphasizing substance and ignoring procedure", and procedure cannot be taken as the direct origin of judicial authority in China. The formation of authority needs two factors: due procedure and public recognition. But there is still a problem: the argumentation of legitimacy of power comes from the Constitution and laws, while legitimacy of the Constitution and laws comes from organ of power. Such vicious circle is easily destroyed and leads to legitimation crisis. In this logic, the biggest problem is the lack of procedure as the bridge between public recognition and legitimacy of the organ of power. Therefore, due process is one of the origins of authority.

First of all, judicial procedure is the bridge between public recognition and judicial independence. Public recognition and judicial independence are the two major origins of judicial authority, but to some extent, there is tension, sometimes conflict, between them. The public evaluation of judicial authority is, on one hand, to decide whether it is in line with the vague justice in their mind, on the other hand, to observe whether it severely violates procedure. The former easily leads to manipulation of public opinion to judicature, which destroy judicial independence and weaken judicial authority. The latter can evaluate substantive judgment through procedural restraint, the essence of which is the supervision of judicature. Through judicial procedure, judicial independence and social supervision reach a balance. Therefore, procedure as a bridge connects public opinion and judicial power -two origins of judicial authority.

Secondly, judicial procedure is the basis of rational authority. The ideology in pre-modern society is single, so that authority came from blood lineage and brute force and procedure didn't play an important role in forming authority. However in modern society, the relationship between individuals is contract, not identity. Blood lineage wasn't the reason of authority any more. Authority needs rational argumentation and choice, while procedure is just right the original point of rational argumentation and choice. Procedure produces competition between different appeals, proposition and value judgment under equal conditions, which makes the most convincing option as the result and makes the decision with rational authority.

At last, the way of discussing judicial procedure makes judicial decisions more authoritative. In impartial procedure, propositions and objections from all parties are full expressed, while value and benefits on different levels are comprehensively weighed and examined. This way of discussion can furthest absorb dissatisfaction and achieve impeccable explanation and judgment. Decisions made through this way can narrow protest and doubt and can be accepted by people easily. Therefore, decisions made through legitimate procedure are more authoritative.

\section{Conclusion}

The main purpose of this paper is not to save the declining judicial authority, so, the author doesn't intend to make a suggestion, but merely analyze the origins of judicial authority in theory. However, analysis of the origin of judicial authority contributes to achievement of the following conclusions: 1.That judicature is interfered by administrative organs is attributed to the low-status of judicial power in power system. The mere requirement of judicial independence cannot solve this problem, and the only solution is intensifying judicial power. 2. It is a fact that judicature is influenced by public opinion, the basis of which is that public recognition is the origin of judicial authority. Therefore, the reduction of public influence needs the other two origins of judicial authority - due procedure and judicial power. 3. Procedure is the bridge between public recognition and judicial power. Therefore, public legal sense needs to be cultivated, so as to restrain public supervision and criticism on procedural level.

\section{References}

Cai, Yingxia. (2008). Precaution of Trial by Media. Legal System and Social Development, Vol. 5.

Chen, Guangzhong, \& Xiao, Peiquan. (2011). On Judicial Authority. Political and Legal Forum, Vol. 1.

Dong, Lijun. (2003). On Judicial Authority. Hunan Social Science, Vol. 1.

Feng, Yiwen. (2009). Judicial Unfairness or Judicial Incapability-On Causes and Solutions of Current Declining Judicial Authority in China. Hebei Law, Vol. 6.

James S. Coleman. (1999). Basis of Social Theory (p. 72). Social Sciences and Academic Press. 
Ji, Weidong. Meaning of Legal Procedure-Another Thinking of China's Legal Construction (p. 91). China Legal Publishing House.

Joseph Raz, \& Zhu, Feng. (translated). (2005). Legal Authority: Collected Papers of law and Morality (p.7). Law Press.

Leslie Lipson, \& Liu, Xiao. (translated). (2001). The Great Issues of Politics-An Introduction to Political Science. (pp. 176-179, pp. 187-201). Huaxia Publishing House.

Liu, Lianjun. (2013). Populism of Judicature. Legal Science, Vol. 1.

Liu, Yang. (2008). Transformation of the Opinion of Legitimacy of Law-Based on Western Two Major Schools (p. 57). Peking University Press.

Ma, Guixiang. (2004). Authority, Legal Authority and Judicial Authority. Politics and Law, Vol. 5.

Pan, Xiaojun. (2005). On Judicial Authority. Inner Mongolia Social Science, Vol. 3.

Sichuan Superior People's Court Research Group: Survey Report of Judicial Credibility of Court. Application of Law, Vol. 4, 2007.

Talcott Parsons, \& Liang, Xiangyang. (translated). (1988). Structure and Process of Modern Society (p. 7). Guangming Daily Press.

Wang, Jiancheng, \& Sun, Yuan. (2001). On Judicial Authority and Authoritative Judicature. Law Review, Vol. 4.

Xu, Yang. (2012). Retrial for Public Opinion—Dilemma and Solutions of Judicial Decision-Making. China Law, Vol. 2.

Yang, Tao. (2013). Is No Case-filing with Chinese Characteristics? China Business News, Mar 27th, 2013, A07.

Zhang, Wusheng. (2004). Professionalism and Elitism of Judges and Judicial Authority. Politics and Law, Vol. 5.

Zhang, Zhiming. (2012). On Value Function of China's Case Instruction System. Study and Exploration, Vol.3.

Zhou, Guoxing. (2013). How Trial Responses To Public Opinion-Based on Theory of Situation Sense. Studies in Law and Business, Vol. 3.

Zhou, Wei. (2004). Judicial Fairness: Formation Basis of Judicial Authority. Politics and Law, Vol. 5.

\section{Notes}

Note 1. See Supreme People's Court Working Report (The Fifth Session of the Eleventh National People's Congress), from official website of Supreme People's Court of the People's Republic of China, http://www.court.gov.cn/qwfb/gzbg/201204/t20120413_175925.htm

Note 2. Leslie Lipson is the first one to distinguish authority of dictatorial government from democratic government. There are three origins of dictatorial authority: 1. Power granted by the God. 2. Might is right. 3. Ancestral Lineage. The authority of democratic government comes from people's recognition and authorization.

Note 3. Referring to the model of authority origin proposed by Weber, Prof. Wang Jiancheng holds that judicial authority comes from belief, tradition and rationality. This kind of classification is inclined to common judicial tradition, especially the judicial tradition centered by western countries. Western judicature possesses strong religious origin, so we can say that judicature comes from belief. Western judicature came down in one continuous line, and didn't experience separation and violent change, so we can say that judicature comes from tradition. Western judicature was established on the basis of formal rationality, so we can say judicature comes from rationality. However, Prof. Wang Jiancheng didn't investigate Chinese practical situations. In China, religion makes little influence on judicature, while Confucianism that influences judicature cannot be considered as belief. Therefore, Chinese judicial authority doesn't come from belief. After the breakup of Chinese Legal System, Chinese judicature experienced fragment to reintegration. Therefore, Chinese judicial authority didn't effectively inherit the tradition, so that we cannot say judicial authority comes from tradition. According to Weber's classification, Chinese Law is irrational in essence, and cannot change in a short time. Therefore, it is not proper to say that Chinese judicial authority comes from rationality.

Note 4. In Raz's opinion, if one can influence people's destiny and choice, he owns effective authority.

Note 5. Some organs owning strong power, such as National People's Congress, don't have authority in some aspects, because some of their functions are not exercised in these aspects. In addition, the authority of both judicature 
and the Constitution lies in implementation of judicial power. Professor Xi emphasizes that life and authority of the Constitution lies in implementation on the 30th anniversary of the implementation of China's 1982 Constitution. See China Daily, Dec. 4th, 2012. http://news.xinhuanet.com/politics/2012-12/04/c_113907206. $\mathrm{htm}$

Note 6. These methods include but not limit to the following ones: 1. Establishing judicial authority; 2. Intensifying communication between judicature and society, so as to win public understanding; 3.Courts not influenced by public opinions; 4. Rational response to public opinion; 5. Punishing the media for improper reports through judicial power; 6 . Setting the limit for media comments.

Note 7. Such as Xu Ting was measured below statutory sentence, which is not in line with corpus delicti and legal provisions, that doesn't accord with substantive justice. But compared to life imprisonment, it is accepted by people, so that the query on judicial organ by people is reduced. 